This electronic version on http://ansaraonline.com is an article published in:

Ansara, Y. G., \& Hegarty, P. (2011). Cisgenderism in Psychology: Pathologizing and misgendering children from 1999 to 2008. Psychology \& Sexuality, iFirst, 1-24.doi: 10.1080/19419899.2011.576696.

Psychology \& Sexuality is available online at: http://www.tandf.co.uk/journals/rpse

This article is available online at:

http://www.tandfonline.com/doi/abs/10.1080/19419899.2011.576696

**Please contact Taylor $\&$ Francis for third party public posting permission.**

\title{
Cisgenderism in psychology: pathologising and misgendering children from 1999 to 2008
}

\author{
Y. Gavriel Ansara and Peter Hegarty
}

Department of Psychology, Faculty of Arts and Human Sciences, University of Surrey, Guildford, UK

Author correspondence email: gavriel.ansara@gmail.com

\begin{abstract}
:
We assessed whether recent psychological literature on children reflects or contrasts with the zeitgeist of American Psychological Association's recent non-discrimination statement on 'transgender' and 'gender variant' individuals. Article records $(N=94)$ on childhood 'gender identity' and 'expression' published between 1999 and 2008 inclusive were evaluated for two kinds of cisgenderism, the ideology that invalidates or pathologises self-designated genders that contrast with external designations. Misgendering language contradicts children's own gender assignations and was less frequent than pathologising language which constructs children's own gender assignations and expression as disordered. Articles on children's gender identity/expression are increasingly impactful within psychology. Cisgenderism is neither increasing nor decreasing overall. Mental health professionals are more cisgenderist than other authors. Articles by members of an 'invisible college' structured around the most prolific author in this area are more cisgenderist and impactful than other articles. We suggest how authors and editors can implement American Psychological Association policy and change scientific discourse about children's genders.
\end{abstract}

Keywords: cisgenderism; content analysis; 'gender identity disorder'; misgendering; pathologising; transgender; transsexual

\section{Introduction}

In August 2008, the American Psychological Association (APA) Council of Representatives adopted the Resolution on Transgender, Gender Identity and Gender Expression Non-Discrimination, acknowledging that 'transgender and gender variant people frequently experience prejudice and discrimination and psychologists can, through their professional actions, address these problems at both an individual and a societal level' (American Psychological Association [APA], 2008, para 1). In this document, APA's Council of Representatives recognised that 'psychological research has the potential to inform treatment, service provision, civil rights and approaches to promoting the well-being of transgender and gender variant people' (APA, 2008, para 12) and that 'psychologists are in a position to influence policies and practices in institutional settings' (APA, 2008, para 11). The APA defined the 'professional role' of psychologists as one that requires "the provision of appropriate, nondiscriminatory treatment to transgender and 
gender variant individuals' (APA, 2008, para 17), urging psychologists 'to take a leadership role in working against discrimination towards transgender and gender variant individuals' (APA, 2008, para 17).

Among 'transgender and gender variant individuals', children are uniquely at risk for severe consequences of discrimination. As acknowledged in the APA resolution, many of these children face multiple risks to their well-being, including 'harassment and violence in school environments, foster care, residential treatment centers, homeless centers and juvenile justice programs' (APA, 2008, para 10). Unlike adults, children in most countries do not have the legal right to make autonomous decisions about their educational or living environments. The lack of these legal rights means that children who experience discrimination may benefit even more than adults from advocacy on their behalf by psychologists.

The APA resolution demonstrates how some psychologists have begun to respond to the disparity between mainstream psychological theories and 'transgender and gender variant' individuals' accounts of their own genders. Some time ago, Parlee (1996) identified misrepresentation of such individuals by psychologists, and asserted that psychological approaches to gender research were overwhelmingly pathologising. Parlee found that psychologists failed to identify participants' genders on participants' own terms, remaining limited to theories and terms that view external classifications as more authoritative than self-designations. More recently, other authors have addressed erasure (Namaste, 2000), maligning language (Winters, 2008) and pathologising (Namaste, 2000; Serano, 2007; Winters, 2008) of participants' genders. Namaste's (2000) social critique was informed by qualitative interviews she conducted for community outreach projects; her text provides detailed narratives that were absent from official agency reports. Serano (2007) also critiqued cissexism, traditional sexism, oppositional sexism, effemimania and ungendering in psychomedical literature on 'trans and gender variant' individuals. Both authors echoed Parlee's (1996) view that psychological literature omits people's experiences 'as they are lived and socially organised' (Namaste, 2000, p. 65).

Some authors have critiqued psychological research for similar problems, including the failure to respect children's own gender designations (e.g., Winters, 2008). The recognition of children's own genders is essential both to APA's desired leadership role in ending discrimination (APA, 2008) and to APA's stated goal of 'objectivity in scientific reporting', through 'reducing bias in language' (APA, n.d.). Accordingly, the present content analysis examined recent psychological research on children to evaluate whether the sentiments expressed in the 2008 APA policy reflect or contrast with the zeitgeist of the journal article literature.

\subsection{Psychological approaches to children with self-designated gender and expression}

In this article, we use the term self-designated gender to refer to a child's self-identified gender. We also use the term majority world to refer to the approximately $83 \%$ of the world that is not typically included in the minority of the world that is called "western' or 'developed' (Majority World, n.d.; see also Alam, n.d.). This majority world includes a number of indigenous societies that are situated within geopolitical borders claimed by minority world states. While most children worldwide learn to identify themselves with gender categories, many majority world societies offer traditional pathways for children to self-designate or change their recognised gender category (e.g., Bartlett, Vasey, \& Bukowski, 2000; Davies, 2007; Graham, 2004; Honingmann, 1964; Vasey \& Bartlett, 2007). However, minority world mental health professions have historically viewed children whose self-designated 
gender differs from the gender category to which they were assigned as having a mental disorder (Bryant, 2008; Hill, Rozanski, Carfagnini, \& Willoughby, 2005; Vasey \& Bartlett, 2007).

Psychologist John Money and his colleagues initiated this field of research during the 1950 s when they began studying the concept of 'gender' in children whose biology did not conform to social norms of 'male' or 'female' (e.g., Hampson, Hampson, \& Money, 1955; Money, Hampson, \& Hampson, 1955a, 1955b). During the 1960s, Richard Green coauthored several studies with John Money on 'effeminate' behaviour in boys (e.g., Green \& Money, 1960, 1961, 1962); Richard Stoller was also a leading researcher during that decade (Bryant, 2008). Psychological literature documents the use of behavioural modification to 'fix' children's gender identities and expression throughout the 1970s. Spearheaded by George Rekers, this research addressed topics that included 'deviant sex-role behaviors' (Rekers \& Lovaas, 1974), 'feminoid boys' (Rekers \& Yates, 1976) 'a pre-transsexual boy' (Rekers \& Varni, 1977) and 'childhood gender disturbance' (Rekers, Rosen, Lovaas, \& Bentler, 1978).

In 1980, 'gender identity disorders' first entered the American Psychiatric Association's Diagnostic and Statistical Manual (American Psychiatric Association, 1980). However, as documented by Bryant (2008), the 'Gender Identity Disorder of Childhood' (GIDC) model dates back to the 1960s. Indeed, related concerns can be seen in Terman and Miles's writings from the 1930s (Hegarty, 2007). Between 1980 and the present, various psychological approaches have been proposed to 'treat' children classified as having a 'GIDC' (Bryant, 2006). Currently, Zucker and Bradley's (1995) version of this model is the most widely used approach to these children in psychology. This approach involves behavioural modification techniques and aversive conditioning to 'fix' genders that do not match children and adolescents' external gender assignments (Spiegel, 2008; Zucker \& Bradley, 1995). While this model emerged decades after Rekers and Varni's (1977) article on the 'pre-transsexual' child and some of their original terminology has been replaced by newer terminology, both approaches share a focus on preventing transsexual adulthoods.

One example of Zucker and Bradley's (1995) method involved restricting the gender expression of a five-year-old self-designated girl:

Bradley would no longer be allowed to spend time with girls. She would no longer be allowed to play with girlish toys or pretend that she was a female character [ . . . As her pile of toys dwindled, [Bradley's mother] realized Bradley was hoarding. She would find female action figures stashed between couch pillows. Rainbow unicorns were hidden in the back of Bradley's closet. Bradley seemed at a loss, she said. They gave her male toys, but she chose not to play at all [. . . Bradley would populate her pictures with the toys and interests she no longer had access to - princesses with long flowing hair, fairies in elaborate dresses, rainbows of pink and purple and pale yellow. So, under Zucker's direction, [Bradley's mother] and her husband sought to change this as well. (Spiegel, 2008; misgendering pronouns corrected)

Bradley's mother described the negative impact of this aversive conditioning:

'She was much more emotional ... [. . . ] She didn't want to go to school anymore,' she says. 'Just the smallest thing could, you know, send her into a major crying fit. And ... she seemed to feel really heavy and really emotional.' (Spiegel, 2008; misgendering pronouns corrected)

Some psychological publications have critiqued Zucker and Bradley's (1995) approach as problematic or archaic (e.g., Burke, 1996; Hegarty, 2009; Hill et al., 2005; Langer \& Martin, 2004; Lev et al., 2010; Wilson, Griffin, \& Wren, 2002). Some psychological models have also discarded direct behavioural modification for therapeutic interventions described in psychological literature as 'supportive' and 'affirmative' towards children's self-designated genders (e.g., Hill, Menvielle, Sica, \& Johnson, 2010; Klein, 2009; Raj, 2008; Vanderburgh, 2009). 
Indeed, some recent psychological approaches suggest an ideological shift in minority world psychomedical discourse from depicting 'gender variance' as pathology to viewing self-designated gender as a natural phenomenon. For example, Herbert Schreier, a child psychologist based at Oakland Children's Hospital and Research Center, has described 'gender variance' not as 'GIDC' but instead as children 'becoming more aware of how it is to be themselves' (Brown, 2006, p. 2, para 1). Therapist Diane Ehrensaft has assisted some children in achieving social recognition for their self-designated genders. Ehrensaft 'does not think parents should try to modify their child's behavior' and 'does not see transgenderism itself as a dysfunction' (Spiegel, 2008, Section 'Another Family, Another Approach', para 16). Adolescent psychiatrist Edgardo Menvielle, founder of a US-based outreach group for parents of 'gender variant' children that now has over 200 members, asserts that 'the goal is for the child to be well adjusted, healthy and have good self-esteem' (Brown, 2006, p. 2, para 3).

While some of these newer models appeal directly to children's well-being and autonomy, many also support the eradication of children's self-designated genders for paternalistic reasons. For example, one recent psychological approach describes the erasure of children's self-designated gender and expression as a positive therapeutic outcome because the intervention aims to reduce 'comorbid' behaviour associated with 'extreme cross-gender' behaviour (Rosenberg, 2002). Thus, even some 'supportive' approaches use pathologising terms like 'severe', 'conditions', 'extreme' and 'comorbidity', similar to earlier clinical models designed to reduce 'atypical' gender behaviour (see also Roen, 2011).

Some authors contend that mental health professionals and psychology at large are lagging behind other arenas in their lack of recognition and support for children's own self-designated genders (e.g., Kennedy, 2008; Lelchuk, 2006; Winters, 2008). Others suggest that psychologists are adopting more positive attitudes over time. Brown (2006, p. 1) argued that 'until recently, many children who did not conform to gender norms in their clothing or behaviour and identified intensely with the opposite sex [sic] were steered to psychoanalysis or behaviour modification', but that nowadays 'children as young as 5 . . are being supported by a growing number of young parents, educators and mental health professionals'. Similarly, Hill and Willoughby (2005, p. 532) argue that while 'early studies of attitudes toward transsexuals among medical and psychiatric professionals documented fairly negative views. . . attitudes among mental health professionals seem to be fairly positive 20 years later'. However, questions about the nature and stability of approaches towards children among mental health professionals and psychologists more generally remain open. We addressed them here through a content analysis of the psychological literature.

\subsection{Cisgenderism}

This research focused on children with self-designated genders that differed from those assigned by the psychological researchers who studied them. We are not the first to theorise the ideologies that might lead such children to be misunderstood. Prejudice and discrimination researchers have discussed 'transphobia' (Hill \& Willoughby, 2005; Nagoshi et al., 2008; Sugano, Nemoto, \& Operario, 2006; Winter, Webster, \& Cheung, 2008), 'genderism' (Browne, 2004; Hill \& Willoughby, 2005) and 'anti-trans prejudice' (Tee \& Hegarty, 2006). Transphobia has been described as 'an emotional disgust toward individuals who do not conform to society's gender expectations' (Hill \& Willoughby, 2005), akin to 'homophobia' (Weinberg, 1973). Hill and Willoughby (2005) developed a transphobia scale that predicted parents' reactions to gender non-conforming children (see also Martin, 1990). Measures of transphobia and homophobia are correlated (Nagoshi et al., 2008), and 
exposure to transphobia can impact safer sex practices (Sugano et al., 2006) and can traumatise (Mizock \& Lewis, 2008). In 'transphobia' research, violence and discrimination against people with self-designated genders are typically attributed to negative attitudes towards people with 'transgender identity', and this literature relies heavily on categorical notions like 'the transgender community', 'transgender people', 'transgenders', 'transgenderists', 'transsexuals' or 'transpeople' (e.g., Hill \& Willoughby, 2005; Mizock \& Lewis, 2008; Tee \& Hegarty, 2006; Winters, 2008).

However, the 'transphobia' concept fails to challenge two assumptions. The first is the notion that is implicit in the terms 'trans' and 'gender variant', that people with self-designated gender lie 'across from' or 'vary from' normative human development. Second, the transphobia framework fails to challenge the assumption that 'trans people' and 'cisgender or cissexual people' constitute distinct classes of individuals. We think that these shortcomings exemplify the ways that 'prejudice' and related constructs often emphasise individual attitudes and divert attention away from systemic problems (Billig, 1991; Fernando, 2009; Kitzinger, 1987). For these reasons, many lesbian, bisexual and gay researchers have abandoned the term 'homophobia' in favour of such terms as 'heteronormativity' (Warner, 1993), 'heterosexism' (Herek, 1990) and 'sexual prejudice' (Herek, 2000). We argue that a similar shift is needed to properly engage with the social systems that children with self-designated genders must navigate. Accordingly, we use the term cisgenderism $^{2}$ to name this ideology.

We use the term cisgenderism for three reasons. First, unlike 'transphobia', cisgenderism describes a prejudicial ideology, rather than an individual attitude, that is systemic, multi-level and reflected in authoritative cultural discourses. Second, while 'transphobia' and 'genderism' purport to contrast treatment of different types of people, cisgenderism problematises the categorical distinction itself between classes of people as either 'transgender' or 'cisgender' (or as 'gender variant' or unmarked) (see also Miller, Taylor, \& Buck, 1991). Our thinking is informed by research that shows that such categorical distinctions can themselves be components of prejudicial ideologies in areas such 'race', gender and sexual orientation (Haslam \& Levy, 2006; Keller, 2005; Martin \& Parker, 1995; Prentice \& Miller, 2007; Williams \& Eberhardt, 2008). We consider cisgenderism to be a form of 'othering' that takes people categorised as 'transgender' as 'the effect to be explained' (Ansara, 2010), consistent with theorising about 'race' and ethnicity (DuBois, 1903/2005), 'sex' (de Beauvoir, 1949/1974), 'gender' (Roughgarden, 2004), 'disability' and 'special needs' (Allen, 1999), 'humanity' (Bradshaw, 2009; Marcu \& Chryssochoou, 2005), sexuality (Warner, 1993) and their intersections (Burman, Gowrisunkur, \& Sangha, 1998; Purdie-Vaughns \& Eibach, 2008). Thus, cisgenderism may be reflected in psychological research that assumes cisgenderism to be healthy or ideal, just as heterosexist ideology is evident when researchers 'conceptualiz[e] human experience in strictly heterosexual terms. . . consequently ignoring, invalidating, or derogating homosexual behaviors and sexual orientation' (Herek, Kimmel, Amaro, \& Melton, 1991, p. 958) or sexist ideology is evident when researchers consider boys only as their model for human development (e.g., Freud, 1923/1960). Third, cisgenderism provides a clearer frame than 'transphobia' or 'genderism' for evaluating the role of language in science in the dissemination of prejudicial ideology, following similar work in the field of sexist language (e.g., Eichler, 1991; Hyde, 1984; Martyna, 1980).

\subsection{The present study}

In the present study, we examined whether cisgenderism has characterised the language of scientific communication about children in psychology in the period since Parlee's (1996) 
critical article. The study drew conceptually on feminist research (e.g., Diekman, Eagly, \& Johnson, 2010; Gannon, Luchetta, Rhodes, Pardie, \& Segrist, 1992; Sherif, 1998; Voss \& Gannon, 1978) and content analyses of psychological literature (e.g., Ader \& Johnson, 1994; Edwards \& Pedrotti, 2008; Morin, 1977), in its assumption that scientific language about participant groups both represents and perpetuates ideology. We evaluated article records (i.e., abstracts, keywords, subjects, titles, etc.) archived on PsycINFO for two kinds of cisgenderism. Pathologising is the construction of people's behaviour or characteristics as pathological or disordered (Newcomb, 1996; Winters, 2008). The diagnostic classification of self-designated gender as a 'disorder' led us to predict that pathologising language would be common. Pathologising items that addressed a focus on assessment and evaluation were based on Herek et al.'s (1991) guidelines for avoiding 'heterosexist bias' in psychological research. Misgendering ${ }^{3}$ occurred where psychologists categorised a child into a gender category or gendered behavioural description with which the child themselves did not identify.

To assess claims that accounts of 'transgender people' in psychology are becoming more positive, we examined whether cisgenderism was increasing or decreasing in the literature over time. We also assessed whether cisgenderism was unevenly distributed across psychology's sub-disciplines, testing the specific prediction that authors from mental health professions would be more likely to pathologise children with selfdesignated genders. Finally, we examined one problem that might sustain cisgenderism, despite increasing recognition regarding this mechanism. Quiñones-Vidal, Lopéz-García, Peñaranda-Ortega and Tortosa-Gil's (2004) content analysis of the Journal of Personality and Social Psychology (JPSP) showed that citations in that area of psychology were most common among networks of collaborating authors. Quiñones-Vidal et al. classified these networks as 'invisible colleges' (see also de Solla Price \& Beaver, 1966). We tested whether there were similar networks or 'invisible colleges' among authors actively writing about children with self-designated genders and whether the impact of such networks could help us to explain the persistence of cisgenderist theories in psychology. To test this hypothesis, we examined the citation count, or impact, of the articles sampled. Authors in this area sometimes describe citation count as a measure of merit or influence (e.g., Zucker \& Cantor, 2005), but some researchers debate actively the reasons why scientists cite each other and the extent to which high citation counts can be used as a measure of scientific merit (e.g., Bornmann \& Daniel, 2008).

\section{Method}

\subsection{Sample selection}

We sampled articles using PsycINFO, the APA-compiled database that constitutes the largest peer-reviewed literature resource of academic journal articles and other publications in the fields of behavioural science and mental health. We conducted Boolean/Phrase searches by restricting results to English language journal articles published between January 1999 and December 2008 inclusive. We restricted the Age Group field to the following PsycINFO categories: childhood (birth-12 years); neonatal (birth-1 month); infancy (2-23 months); preschool age (2-5 years); and school age (6-12 years), and the Document Type field to journal articles. Books, book reviews, commentaries, conference proceedings, dissertation abstracts and replies were excluded. We counted original articles only and not duplicate entries or reprints. We treated piecemeal publications as distinct cases only when the abstract content differed.

We combined the primary filtering search string ' $\left(\operatorname{child}^{*}\right)$ or $\left(\operatorname{girl}^{*}\right)$ or $\left(\right.$ boy $\left.{ }^{*}\right)$ ', in the first search field, with 74 search terms, phrases or etymological roots that referenced aspects of 
gender and/or gender expression in a second search field (see Appendix). Search results included only article records that matched in both fields (e.g., articles that focused on gender differences between girls and boys but which did not specifically address children's gender identity or expression itself would not have shown up in our search). Search combinations included terms from cross-cultural contexts and addressed both assigned and selfdesignated genders and both 'typical' and 'atypical' gender-associated expression, to capture as many article records as possible. No specific fields were selected for search terms.

After we had removed duplicate entries, 159 article records remained. We excluded 41 articles where the article record did not specifically mention children's assigned or self-designated genders or gender-associated expression in children. In an additional 23 articles, the only mention of search terms occurred in the list of author surnames (e.g., secondary search term 'butch' in the author field under surname 'Butcher'). We excluded these 64 articles and one additional reprint, for a total of 65 excluded articles. We retained 94 article records for this analysis.

Journals with article records included in our sample $(N=49)$ covered a wide range of fields both within and outside of psychology. Most journals published only one article in our sample ( $n=35,71.43 \%)$, including American Behavioral Scientist; Behavior Genetics; British Journal of Sociology; Canadian Journal of Education; Child and Adolescent Social Work Journal; Child Psychiatry and Human Development; Child Welfare Journal; Child: Care, Health and Development; Development and Psychopathology; Educational Psychologist; European Child and Adolescent Psychiatry; Gender and Society; Global Journal of Child Research; Health Education and Behavior; International Journal of Adolescent Medicine and Health; International Journal of Behavioral Development; International Journal of Transgenderism; Journal of Abnormal Child Psychology; Journal of Black Psychology; Journal of Child Psychology and Psychiatry; Journal of Community Psychology; Journal of Developmental and Behavioral Pediatrics; Journal of Personality and Social Psychology; Journal of Pragmatics; Journal of Secondary Gifted Education; Journal of Sex and Marital Therapy; Journal of Sport Behavior; Men and Masculinities; Professional School Counseling; Psychoanalytic Psychotherapy; Psychological Science; Sexuality Research and Social Policy; Social Development; Social Policy; and The Career Development Quarterly. Among the journals in our sample that published more than one article each $(n=14,28.57 \%)$, six journals published two articles each in our sample, including Child and Adolescent Psychiatric Clinics of North America; Early Child Development and Care; Gender and Psychoanalysis; International Journal of Psychoanalysis; Journal of Psychology and Human Sexuality; and The Psychoanalytic Study of the Child. Child Development and Hormones and Behavior each published three articles in our sample; Developmental Psychology and Journal of Gay and Lesbian Social Services published four articles each in our sample. Three journals $(6.12 \%)$ published five or more articles each in our sample. The most prolific journal in our sample was Clinical Child Psychology and Psychiatry $(n=11)$, followed by Archives of Sexual Behavior $(n=9)$, Sex Roles $(n=8)$ and Journal of the American Academy of Child and Adolescent Psychiatry $(n=5)$.

\subsection{Content coding}

We assessed levels of Pathologising and Misgendering language in these article records. We assessed the presence or absence of each of four types of pathologising language in each article record: (1) labelling childhood gender non-conformity (CGNC) as pathology (e.g., 'research on empathy in gender identity disordered boys'); (2) mentioning 
interventions to address CGNC (e.g., 'patient referred to a gender specialist for affirmative therapy'; 'behavioural modifications to reduce cross-gender play'); (3) voicing support for treatment interventions to reduce or stop CGNC (e.g., 'gender-appropriate play therapy reduced the patient's cross-gender desires'); and (4) assessing and $/$ or diagnosing CGNC (e.g., 'screened for gender-appropriate mannerisms', 'Boyhood Femininity Test' or 'sample included 22 girls with gender identity disorder').

Similarly, four kinds of Misgendering were coded: (1) designating participant sex or gender in the Keyword(s), Subject(s) and/or Population(s) fields in a manner that contradicts information about participant self-designated gender in the Abstract (e.g., The population is listed as Male, Keyword boy, and/or Subject boys and the Abstract contains the text 'a participant who thought he was a girl'); (2) mispronouning (Ansara, 2010), which refers to the use of gender-specific pronoun(s) that differ from participants' own gender (e.g., 'This paper reports on a female-to-male transsexual and her psychosocial development' or 'Mary insisted that she was a boy and said to call her John'); (3) using genderspecific nouns (e.g., 'boy', 'girls', 'lesbian', 'daughter', 'brother') that differ from the individual or population's gender identity (e.g., 'Girls in this study reported cross-gender identities as boys'); and (4) labelling participant gender identity and/or expression as inauthentic, dishonest, or fantasy (e.g., 'He pretended to be a girl from ages 18 mo to 4 yrs').

Both the first author and a second coder, who was unaware of the researchers' hypotheses, reliably coded each article record for each individual type of pathologising or misgendering language (see Table 1). While one or more authors typically serve as coders in content analyses (e.g., Buhrke, Ben-Ezra, Hurley, \& Ruprecht, 1992; Imada \& Schiavo, 2005; Peterson \& Kroner, 1992; Simoni, 1996), many content analyses do not use multiple coders for the entire data set as we did (e.g., Buhrke et al., 1992; Peterson \& Kroner, 1992; Simoni, 1996). Cases of disagreement were resolved through discussion as is standard methodology for content analytic studies that use multiple coders. Each article record was coded as 0 if the relevant form of cisgenderism was absent and 1 if present. To calculate pathologising and misgendering language scores, we counted the number of each type of cisgenderism observed and divided by 4 . Therefore, pathologising and misgendering language scores ranged from 0 to 1 .

\subsection{Authorship type coding}

We coded three authorship variables for each article: Mental Health Profession, Gender Clinic Affiliation and Invisible College Membership. Mental Health Profession was coded as 1 when first authors had a listed academic or clinical affiliation to a psychology (including counselling psychology), psychotherapy, psychiatry, or psychoanalysis department or

Table 1. Interrater reliability for cisgenderism items.

\begin{tabular}{lccccc}
\hline Dimension & Item & $\kappa$ & SE & LL & UL \\
\hline Pathologising & 1 & 0.98 & 0.02 & 0.94 & 1.00 \\
& 2 & 1.00 & 0.00 & 1.00 & 1.00 \\
& 3 & 0.90 & 0.04 & 0.83 & 0.98 \\
Misgendering & 4 & 0.94 & 0.04 & 0.85 & 1.00 \\
& 1 & 1.00 & 0.00 & 1.00 & 1.00 \\
& 2 & 1.00 & 0.00 & 1.00 & 1.00 \\
& 3 & 0.96 & 0.03 & 0.90 & 1.00 \\
& 4 & 0.82 & 0.12 & 0.58 & 1.00 \\
\hline
\end{tabular}

Note: $\kappa$, kappa; SE, standard error; LL, lower limit of confidence interval; UL, upper limit of confidence interval. 
clinic or (in the case of authors without a listed professional affiliation) an academic credential at the postgraduate level or above in any field of psychology (including counselling psychology), psychotherapy, psychiatry or psychoanalysis $(n=74,78.7 \%)$ and as 0 otherwise $(n=20,21.3 \%)$. First authors in the field of social work were coded as Non-Mental Health. ${ }^{4}$ Gender Clinic Affiliation was coded as 1 when the first author listed a gender clinic affiliation $(n=22,23.4 \%)$ and 0 otherwise $(n=69,73.4 \%)$. Authors without a gender clinic affiliation listing but with a gender clinic affiliation listed in another article record in this sample were coded as 0 due to the inability to verify their gender clinic affiliation at the time of publication. Three cases for the gender clinic affiliation variable were left blank due to confusing or inconsistent available information.

Membership of the invisible college was determined inductively. The corpus contained articles by 191 authors and most published only once $(n=167,87.4 \%)$. A minority of authors published $2(n=13), 3(n=3), 4(n=3), 5(n=1), 7(n=1)$ or 11 times $(n=1)$. The most prolific author was Kenneth J. Zucker, who authored or co-authored 16 articles $(17.0 \%)$ in the corpus, including the 11 articles co-authored by the next most prolific author Susan Bradley. Accordingly, we assessed membership in the invisible college around Kenneth J. Zucker through co-authorship. Articles authored or co-authored by this author and those authored by one of his co-authors independent of him within this corpus were coded as $1(n=20,21.3 \%)$. Other articles were coded as $0(n=74,78.7 \%)$. The distribution of articles by Mental Health Profession, Gender Clinic Affiliation and Invisible College Membership is shown in Table 2.

\subsection{Article impact}

Two-year impact for each article was calculated by counting the number of citing articles archived in PsycINFO for the publication year plus the two consecutive full calendar years following publication (e.g., for an article published in May 2001, the 2-year impact included times cited from May 2001 through December 2003 inclusive).

\section{Results}

This study was designed to assess whether cisgenderist language has been increasing or decreasing in psychological research in recent times, whether research by mental health professionals is more or less cisgenderist than research by other authors, and whether cisgenderist research is particularly impactful. As the cisgenderism scales were not normally distributed, we used non-parametric statistics throughout the analyses.

Table 2. Count of articles by authorship.

\begin{tabular}{lllllr}
\hline & \multicolumn{2}{c}{ Mental health } & & \multicolumn{2}{c}{ Non-mental health } \\
\cline { 2 - 3 } \cline { 5 - 6 } Discipline affiliation & GC & NGC & & GC & NGC \\
\hline $\begin{array}{l}\text { Invisible college location } \\
\text { Inside }\end{array}$ & 20 & 0 & & 0 & 0 \\
Outside & 50 & 2 & & 4 & 18 \\
\hline
\end{tabular}

Note: GC, gender clinic affiliation; NGC, no gender clinic affiliation. 


\subsection{Cisgenderism over time}

To calculate whether cisgenderism is increasing or decreasing, we calculated bivariate correlations between pathologising, misgendering and year of publication. The two dimensions of cisgenderism were strongly correlated but distinct $(r h o(93)=0.58, p<0.001)$. No significant association was found between year and either pathologising or misgendering ( rho $(93)=-0.02$ and 0.09 , respectively, both $p>0.36$ ). Cisgenderist language remained stable in early twenty-first-century psychology.

\subsection{Mental health professionals and cisgenderism}

There were no articles within the invisible college whose first authors did not have a mental health affiliation. Accordingly, we re-categorised the articles into three distinct groups: those in the invisible college $(n=20)$, and those written by mental health authors $(n=54)$ and non-mental health authors outside the invisible college ( $n=54$ and $n=20$, respectively) (see Table 2). Omnibus Kruskal-Wallis tests revealed differences between these three groups of article records for both pathologising language $\left(\chi^{2}(2, N=94)=34.05, p\right.$ $<0.001)$ and misgendering language $\left(\chi^{2}(2, N=94)=11.12, p=0.004\right)$ (see Figure 1$)$.

Figure 1: Mean difference values $(m \mathrm{~s})$ for cisgenderism

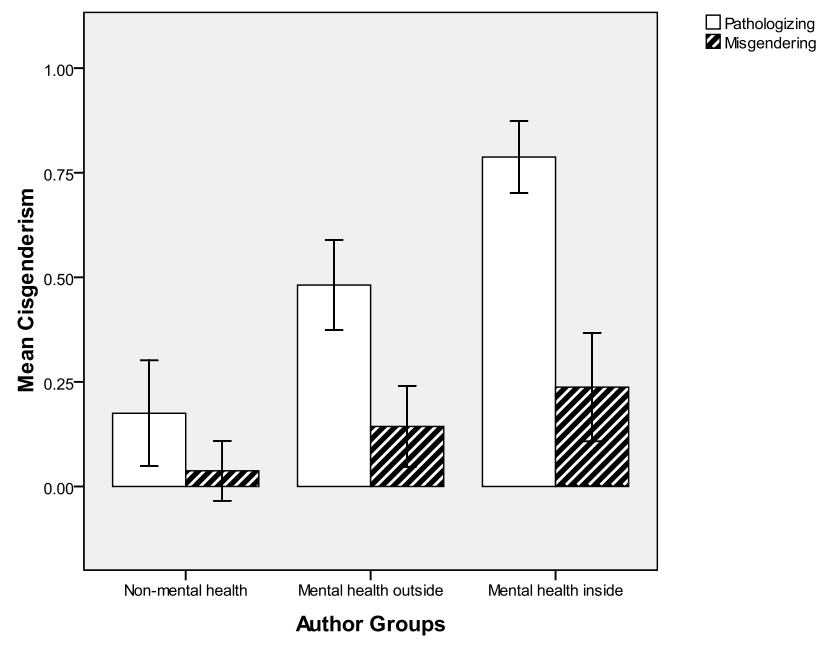

Error Bars: $98.3 \% \mathrm{Cl}$

Figure 1. Mean difference values $(m s)$ representing two kinds of cisgenderism, pathologising and misgendering language, for each authorship group. Significant differences in pathologising were found between all three groups and in misgendering between mental health authors inside the invisible college and non-mental health authors. No significant differences in misgendering were found between mental health authors outside the invisible college and non-mental health authors or mental health authors inside the invisible college. Standard errors are represented in the figure by the error bars attached to each column. 
Mann-Whitney tests were performed to explore these effects further. All possible comparisons between groups were tested with two-tailed significance levels of 0.05 adjusted to 0.017 in accord with Bonferroni corrections. Analysis of the pathologising language scores showed that all three groups were significantly different from each other (all $z>3.64$, all $p$ $<0.001)$. Misgendering language was significantly more pronounced in the article records written by authors within the invisible college than those written by non-mental health authors $(z=3.23, p<0.001)$. Article records written by mental health authors outside the invisible college did not differ in misgendering language from article records written by non-mental health authors $(z=1.42, p=0.16)$ or article records written by mental health authors inside the invisible college $(z=2.35, p=0.019)$ (see Figure 1).

\subsection{Does cisgenderist research have greater impact?}

Next, we evaluated whether impact was associated with cisgenderism. In the sample as a whole, articles were cited on average 2.77 times in the 2 years following publication. Moreover, impact was positively correlated with year of publication ( rho $(94)=0.32$, $p=0.002$ ); the impact of research in this area within psychology is increasing over time. Impact was not correlated with the use of either pathologising or misgendering language in the sample as a whole ( $r h o(94)=0.10$ and 0.01 , respectively, for both $p>0.35$ ). However, a Kruskal-Wallis test showed that impact varied between the three groups of authors $\chi^{2}(2$, $n=94)=19.29, p<0.001)$. Mann-Whitney tests showed that impact was greater among mental health articles written by those inside the invisible college $(M=5.90)$ than among articles written by either mental health authors outside the invisible college $(M=2.33$, $z=2.85, p=0.004)$ or non-mental health authors $(M=0.80, z=4.03, p<0.001)$. Impact also varied significantly between these last two groups of authors $(z=2.78, p=0.005)$.

\section{Discussion}

Cisgenderist language is commonplace when psychologists communicate professionally with their peers about children. Mental health professionals are the authors who are most likely both to pathologise the children they study and to contradict those children's own understandings of themselves in their writings. Among mental health professionals, those who are most closely tied through publication with the most prolific author in the field are also most likely to adopt pathologising and misgendering language. Such authors are also most likely to have their own work cited by later scientific publications. These factors may contribute to the maintenance of cisgenderism in psychology, despite moves within professional bodies like the APA to oppose this ideology. Contrary to the opinions of some psychologists (e.g., Hill \& Willoughby, 2005), cisgenderism - at least with regard to children - does not appear to have been decreasing in psychology in recent years. Rather, Parlee's (1996) claim that psychologists' 'official knowledge' has excluded and dismissed knowledge produced outside of clinical or academic settings by 'transgender and gender variant' individuals remains as relevant as ever. While we used a content analytic method that was designed to identify patterns and systemic components of large data sets efficiently, we hope that our empirical findings will motivate future research using methods suited to deep engagement with the ways that psychological articles characterise and discuss children's genders.

Having documented the stability of cisgenderism towards children in psychology, should we pessimistically predict its future stability? The language and concepts of the 
most prolific and impactful authors in our sample towards children's self-designated genders contrast starkly with the vision of nondiscriminatory leadership espoused by APA policy. While some researchers have explored the extent to which self-citations may inflate impact factor in psychological publications generally (e.g., Anseel, Duyck, De Baene, \& Brysbaert, 2004), some research suggests that removing self-citations from citation counts may introduce methodological problems without removing the total effect of self-citations (e.g., Foley \& Della Sala, 2010). This debate falls outside the scope of the current analysis. Regardless of whether self-citations may have affected our impact variables (indeed selfcitations have been found to affect impact factor across the field), impact factor appears to be the increasingly dominant standard by which research funding decisions, fellowship awards, leadership position appointments, and other assessments of value are made in psychological research (Bornmann \& Daniel, 2008; Foley \& Della Sala, 2010; O’Connor, 2010).

Indeed, the widespread use of impact factor to assess merit in the discipline of psychology may explain why invisible college members not only publish more impactful articles but also predominate on key policymaking committees in the mental health professions such as the American Psychological Association Task Force on Gender Identity, Gender Variance, and Intersex Conditions (e.g., Kenneth J. Zucker), the American Psychiatric Association Workgroup on Sexual and Gender Identity Disorders preparing the 2012 edition of the DSM-5 (e.g., Peggy Cohen-Kettenis and Kenneth J. Zucker) and the World Professional Association for Transgender Health (formerly the Harry Benjamin International Gender Dysphoria Association) Standards of Care Workgroup Committee (e.g., Peggy Cohen-Kettenis and Kenneth J. Zucker). Alternative Standards of Care based on informed consent and harm reduction principles exist outside of these structures (e.g., Dimensions Clinic, 2007; International Conference on Transgender Law and Employment Policy [ICTLEP], 1993). However, these less cisgenderist clinical standards have had little effect on the research literature. The three aforementioned organisations continue to exert the most widespread international influence over policies, diagnostic procedures, and treatment approaches towards people with self-designated genders within psychology and mental health fields. Our findings suggest a pessimistic outlook until such time as these impactful organisations take a stronger position on the use of cisgenderist language.

Far from fulfilling a 'leadership role in working against discrimination towards transgender and gender variant individuals' (APA, 2008, para 17), the continuation of misgendering language in psychology suggests that psychological journal publication policies are falling behind those of other professions. Since 2006, journalists have been directed by the Associated Press to 'use the pronoun preferred by the individuals who have acquired the physical characteristics of the opposite sex [sic] or present themselves in a way that does not correspond with their sex at birth' (Gay \& Lesbian Alliance Against Defamation [GLAAD], 2010). Similarly, The New York Times cautions authors that 'unless a former name is newsworthy or pertinent, use the name and pronouns (he, his, she, her, hers) preferred by the transgender person' and, 'if no preference is known, use the pronouns consistent with the way the individuals live publicly' (GLAAD, 2010). While many journalists continue to disregard these policies, the lack of similar policies against misgendering in psychological publications illustrates the current gap between the APA resolution and current psychological policies.

By way of contrast, a recent article that was published in an APA journal and coauthored by the head of the invisible college identified in our sample referred to participants who self-identified as boys as 'girls with gender identity disorder' in both title and body (Drummond, Bradley, Peterson-Badali, \& Zucker, 2008). Hegarty (2009) critiqued this 
article on the grounds that these children's 'gender identities' had been described as 'disordered' and in need of modification. In response, Zucker, Drummond, Bradley and Peterson-Badali (2009, p. 906) dismissed Hegarty's critique due to its focus on 'politically incorrect language'. By so doing, Zucker et al.'s (2009) rejoinder overlooked the possibility that language might shape research questions, methodology, interpretations and impact (Crasnow, 2008; Danziger, 1990; Messing, Schoenberg, \& Stephens, 1983). Research findings suggest that beliefs in 'political correctness crusaders' are more common among those with conservative gender ideologies (Lalonde, Doan, \& Patterson, 2000). In light of Zucker et al.'s (2009) response, our finding that Archives of Sexual Behavior, a journal for which Zucker serves as editor, was among the two journals that published the largest number of psychological articles on children's genders and expression may explain how editors in this field can fail to notice or address cisgenderist ideology in articles submitted for publication.

Reducing cisgenderist bias in psychological publications on children will require the active collaboration of researchers, editors and leading figures in APA. Yet psychologists and mental health professionals need not turn to journalistic guidelines to accomplish this task, as a minority of authors in our sample offered existing conceptual frames that would decrease cisgenderism in the literature. For example, a programme evaluation study of a cultural intervention with African American girls reported an increase in androgynous gender roles in the intervention group as a positive outcome and noted that the intervention decreased relational aggression (Belgrave et al., 2004). By avoiding the assumption that non-normative gender expression leads to developmental and social problems, Belgrave et al. (2004) gained valuable data that suggests gender normativity and hypernormativity, rather than anormativity, as psychological risk factors for children.

In addition to following Belgrave et al.'s (2004) example, authors can use nonmisgendering language to describe research participants with self-designated genders. For example, authors might describe a participant as a self-designated boy rather than a 'girl who wants to be a boy'. Authors can take care to treat self-designated and externally assigned participants equally. Addressing non-parallel cisgenderist language might mean referring to sample groups in terms of 'self-designated girls and externally assigned girls', rather than providing strictly biological descriptions like 'transsexual natal female' or 'gender variant male' for self-designated young people where gender categories like 'boys and girls' are used for other participants.

Cisgenderism and ethnocentrism may intersect (e.g., Bulilan, 2008; Koyama, 2006). The title of one article in our sample asks, 'can cultural beliefs cause a gender identity disorder?'. This article describes a Thai child's gender as 'disordered' because it contrasts with a minority world psychomedical gender assignment (Tucker \& Jürgen Keil, 2002). Such work fails to acknowledge the cultural nature of psychological science (Danziger, 1990), that all gender assignments are made within cultural contexts, or that the use of biological attributes to assign gender is itself a non-universal cultural practice (e.g., Bartlett et al., 2000; Graham, 2004; Honingmann, 1964; Mitsuhashi \& Hasegawa, 2006; Singh, 2001; Williams, 1992). Rather than be written off as 'culture', some majority world ways of gendering may provide useful guides for the cultural evolution of minority world psychology (e.g., Bulilan, 2008; Jiménez-Domínguez, 2009; Martin-Baró, 1985; Muñoz, 2008).

Another possible intersection of ethnocentrism and cisgenderism of particular relevance to sexuality researchers may occur in the form of coercive queering (Ansara, 2010, p. 181), a type of benevolent cisgenderism that is often present in ostensibly 'supportive' and 'affirming' accounts of children with self-designated gender and which may constitute a form of homonormative ethnocentrism. Coercive queering refers to the practice 
of lumping children with self-designated gender into the categories 'queer' or 'LGBT' without attention to whether this categorisation is consensual or conceptually appropriate. As Bryant's (2008) historical account of the GIDC model suggests, this practice is often situated alongside attempts to distance more acceptable 'homonormative' children from those whose own gender differs from their assigned category. Bryant analysed indepth interviews and analysis of 'LGBTQ' community publications, documenting the harm that the GIDC model has done both to children with same gender attractions and to those whose genders differ from those typically associated with their biology in minority world contexts. Bryant notes that minority world researchers seeking to challenge the GIDC model often defend children with non-normative attractions and social expression while simultaneously positioning children with self-designated genders as the proper targets for pathologising and behavioural modification. It is worth noting that a highly pathologising article record in our sample authored by the director of a gay and lesbian programme documented her efforts to 'fix' the 'gender identity disorders' of children with self-designated genders whose attractions to others were not described in the article record (Rosenberg, 2002). In light of our other results, Bryant's (2008) finding that homonormative 'antihomophobia' critiques of the GIDC model have obscured and pathologised children with self-designated genders suggests that cisgenderism, rather than 'homophobia', accounts for the prevalence of this model. We suggest that researchers exercise caution when using the 'Alphabet Soup Approach' (Ansara, 2010, p. 187) epitomised by umbrella terms like 'queer' and 'LGBT'. Furthermore, social services and clinical programmes that meet the needs of assigned-gender children with same gender attractions may be inappropriate or hostile to children with self-designated genders; careful consideration should be given to the needs of each individual child and to the degree of cisgenderism among staff and policies in each individual setting before determining that a particular 'queer' or 'LGBT' resource is suitable.

More careful survey items in psychological research may also reduce cisgenderism. Instead of treating externally assigned biological categories as authoritative, researchers can ask participants to self-identify their gender and include a separate question regarding whether this self-designation contrasts with an externally assigned classification. Authors can consider the potential error introduced by coding gender uncritically as a single dichotomous variable, leading them to categorise participants in a manner contrary to their self-designation.

Language used to describe identity and behaviour in children with self-designated genders (e.g., 'extreme', 'persistent', 'comorbid') differs substantially from language used to describe the same characteristics in children whose genders and behaviour are normatively aligned with their gender assignments. We can identify this language as cisgenderist based on Eichler's (1991) classification of non-parallel language and asymmetrical concepts as forms of sexist language in research. We therefore consider cisgenderist language to be a type of sexist language that reveals the influence of ideology on psychological science. As Eichler notes in her critique of 'gender dysphoria syndrome', individuals can be judged to suffer from a 'gender identity disorder' . . . 'when they admit to liking to cook, being interested in theatre news, liking flowers and houseplants, and so on' (Eichler, 1991, p. 121). The wide scope of 'disordered' activities from which children may be barred or discouraged raises serious ethical concerns about the use of cisgenderist language in psychological literature.

Cisgenderist ideology reaches beyond science and touches on children's basic human rights. The United Nations Convention on the Rights of the Child (UNCRC) (1989), an international human rights treaty that has been ratified by over 190 nations and all members 
of the United Nations except Somalia and the United States (Kielburger \& Kielburger, 2009), guarantees all children the right to unrestricted freedom of play and expression, both of which are pathologised by current DSM-IV-TR diagnoses (American Psychiatric Association, 2000) and those proposed for DSM-5 (to be published in 2012; see APA, 2010). We agree with Zucker, Bradley, Owen-Anderson, Kibblewhite and Cantor (2008, p. 287) that there are no good epidemiological prevalence studies of 'GID' and that 'accordingly, we have been limited in our research, which now spans 30 years, to the study of clinic-referred children' (emphasis added). This acknowledgement is consistent with our finding that research has been predominantly limited to children seen only in clinical contexts wherein children's definitions of themselves have been effectively erased. This erasure persists despite recent findings from researchers using participatory methods that children can be knowledgeable and competent co-researchers whose own experiences, perceptions and social agency are often necessary for successful health interventions (e.g., Bergström, Jonsson, \& Shanahan, 2010; Conroy \& Harcourt, 2009). Medical providers who are given discretionary authority frequently misjudge when children experience physical pain, are capable of experiencing pain, or are in need of pain medication, when they discount and contradict children's self-reports (e.g., Atkinson, Chesters, \& Heinz, 2009; Schechter, 1989; Walco, Cassidy, \& Schechter, 1994; Weisman, Bernstein, \& Schechter, 1998). Similarly, mental health professionals who misgender may leave children in distress unnecessarily due to their failure to recognise how children determine their own genders and their expression. Ehrensaft cautions, 'If we allow people to unfold and give them the freedom to be who they really are, we engender health. And if we try and constrict it [...], we engender poor mental health' (Spiegel, 2008, para 16).

The high risk of violence and harassment noted in the APA resolution suggests that critical interventions by psychologists are needed in school systems and in the realm of public policy. Even 'affirmative' clinical interventions can promote cisgenderism and lead to 'poor mental health' outcomes when they focus solely or primarily on the intrapsychic issues of children with self-designated gender, thereby failing to address the systemic inequities that some authors (e.g., Giordano, 2008; Marksamer, 2008; Roen, 2011) suggest are largely responsible for these children's problems. Some clinicians have already adopted this approach. Raj (2007) describes how people with self-designated gender can benefit from therapeutic interventions in the form of advocacy and activism to address societal inequities.

New forms of medical intervention prompt further need for reflection about cisgenderism. Several clinics and physicians now offer hormone blockers that delay pubertal changes, an option made available by recent developments in paediatric endocrinology (Möller, Schreier, Li, \& Romer, 2009; Roen, 2011). These hormone blockers may facilitate socialisation with peers of children's own self-designated gender, prevent severe distress and inhibit physiological changes that are difficult to reverse without expensive adult surgical interventions (Giordano, 2008; Marksamer, 2008; Roen, 2011). However, access to hormone blockers for young people typically requires evaluation and approval by mental health professionals, even in countries where pathways for adult access to hormones are available outside of mental health contexts. Thus we urge mental health professionals to challenge cisgenderism through advocacy and policy changes and by increasing access to medical technologies, rather than by adopting an intrapsychic 'affirming' approach that does little to address cisgenderist structural violence.

Psychological research on these children could also contribute significantly to children's rights in legislative and public policy contexts. Numerous school systems around the world have already implemented policies designed to promote inclusion and well-being of 
students with self-designated genders or expression (Brown, 2006; Lelchuk, 2006; Marech, 2004), such as a school district in north-east Thailand that has created separate 'transsexual bathrooms' for students designated 'male" 5 at birth who have a self-designated gender (Head, 2008). ${ }^{6}$ In 2004, the Family Court of Australia approved a sex designation change on the birth certificate and official documents of a 13-year-old boy seeking legal recognition of his self-designated gender (Sandor, 2007). In 2007, an Argentine court approved the first legally sanctioned gender affirmation surgery for a minor in the nation (Schweimler, 2007). Psychologists with a sincere desire to 'affirm' children's own genders can advocate within their local legislative and educational systems for similar advances.

\subsection{Conclusion}

Where some researchers (e.g., Zucker et al., 2009) see mere semantics, others consider sexist language an abusive and destructive form of hate speech (e.g., Lillian, 2007). Cisgenderist language can function to dehumanise, silence and erase. Indeed, even Parlee's (1996) important criticism of cisgenderist language is limited by numerous instances of misgendering, ${ }^{7}$ an illustration that shifting the discourse is extremely difficult even for those engaged in critical analysis. Editors, peer reviewers, psychological researchers, mental health professionals and professional organisations all have ethical duties to address institutional cisgenderism, including cisgenderism that is institutionalised in scientific communication. Children's self-definition and self-expression are not the only issues at stake. The moral integrity of psychology and its public image as an agent of the greater social good depends, in part, upon implementation of APA policy - which our current findings suggest has yet to impact how psychological scientists construct knowledge.

\section{Acknowledgements}

This article is based on an M.Sc. dissertation by the first author under the supervision of the second. We thank Israel Berger for research assistance. We thank Martyn Barrett, Israel Berger, Gay Bradshaw, Chris Fife-Schaw, Brian Kovacs, Zoe Walton and Dan Shepperd for their feedback on previous drafts.

\section{Notes}

1. Note that 'scientific objectivity' has been used to obscure prejudicial ideologies focused on marginalised populations and that many scientists have critiqued 'objectivity' as a social construct that is fashioned from the subjective experiences of the researchers. See Crasnow (2008); Danziger (1990); Fairchild (1991); Fernando (1988), (2009); Jiménez-Domínguez (2009); Spanier (1995); and Stanley and Wise (1983) (esp. p. 174).

2. This term is derived from the Latin-derived prefix cis, meaning 'on the same side' in contrast to the prefix trans-, meaning 'across from'. The term cisgenderism (Ansara, 2010; Serano, 2007) is derived from cisgender (Buijs, 1996; Defosse, 1994).

3. Adapted from Serano's (2007) usage of the verb 'ungendering' to define 'an attempt to undo a trans person's gender by privileging incongruities and discrepancies in their gendered appearance that would normally be overlooked or dismissed if they were presumed to be cissexual'. Note that the current analysis defines a categorical distinction between 'cissexual' and 'transsexual' classes of people as problematic.

4. This classification reflects social work's emphases on the impact of public policy and social environments that affect individuals and on challenging societal inequities (NYU Silver School of Social Work, n.d.).

5. See Laqueur (1990) and Parlee (1996) for critiques of psychologists' treatment of 'sex' as an ahistorical, 'scientific' construct and the social construction of a sex/gender binary as 'official knowledge'. See Spanier (1995) on how gender ideology influences molecular biology. 
6. In Thai society, these self-designated genders include kathoey, girls, and phuying praphet song (a second kind of woman) (Winter, 2006). The term kathoey is a self-designated gender associated with the gender of man or boy who identify as 'gender nonconforming' in some way (Winter, 2006), though some kathoey identify as women (Matzner, 2001). While some Thai people self-identify as kathoey, this term is considered pejorative and inaccurate when used to refer to people who have self-designated genders of phuying (women) or phuying praphet song ['a second kind of woman' (Winter, 2006)]. Each of these terms has divergent meanings and implications that vary by context. See Matzner (2001) and Winter (2006) for discussion of the distinctions between these three Thai genders.

7. For example, Parlee describes Brandon Teena as 'a woman living as a man' (p. 631) and refers to him using female pronouns (e.g., 'her'); describes the first 'FTM Conference of the Americas' as an event 'for women living, dressing, or having surgery to become, men' (p. 631); and refers to Tyra Hunter, a woman with a self-designated gender, as a 'crossdresser' and 'man' (p. 632).

\section{Notes on contributors}

Y. Gavriel Ansara, MSc, is a PhD candidate and an academic tutor in the Department of Psychology at the University of Surrey.

Dr Peter Hegarty is a Reader in Psychology and Deputy Head of Department in the Department of Psychology at the University of Surrey.

\section{References}

Ader, D., \& Johnson, S. (1994). Sample description, reporting, an analysis of sex in psychological research: A look at APA and APA division journals in 1990. American Psychologist, 49, 216-218. doi:10.1037/0003-066X.49.3.216.

Alam, S. (n.d.). Reframing the majority world. Retrieved from http://auroraforum.stanford.edu/files/ transcripts/Aurora_Forum_Essay_Shahidal\%20Alam_Reframing\%20the\%20Majority\%20World.10. 01.07.pdf

Allen, C. (1999). Disablism in housing and comparative community care discourse - Towards an interventionist model of disability and interventionist welfare regime theory. Housing, Theory and Society, 16, 3-16.

American Psychiatric Association. (1980). Diagnostic and statistical manual of mental disorders (3rd ed.). Washington, DC: American Psychiatric Association.

American Psychiatric Association. (2000). Diagnostic and statistical manual of mental disorders (4th ed., text rev.). Washington, DC: American Psychiatric Association.

American Psychiatric Association. (2010). Sexual and gender identity disorders. Retrieved from American Psychiatric Association, DSM-5 Development, Proposed revisions. Retrieved from http://www.dsm5.org/ProposedRevisions/Pages/SexualandGenderIdentityDisorders.aspx

American Psychological Association. (n.d.). APA Style: What's new in the 6th edition [Audiovisual web tutorial], slide 12. Retrieved from http://flash1r.apa.org/apastyle/whatsnew/index.htm

American Psychological Association. (2008, August). Resolution on transgender, gender identity, and gender expression non-discrimination. Retrieved from http://www.apa.org/pi/lgbc/policy/transgender.html

Ansara, Y.G. (2010). Beyond cisgenderism: Counselling people with non-assigned gender identities. In L. Moon (Ed.), Counselling ideologies: Queer challenges to heteronormativity (pp. 167-200). Aldershot: Ashgate.

Anseel, F., Duyck, W., De Baene, W., \& Brysbaert, M. (2004). Journal impact factors and self-citations: Implications for psychology journals. American Psychologist, 59(1), 49-51. doi:10.1037/0003066X.59.1.49

Atkinson, P., Chesters, A., \& Heinz, P. (2009). Pain management and sedation for children in the emergency department. British Medical Journal, 339, 1074-1079. doi: 10.1136/bmj.b4234.

Bartlett, N., Vasey, P., \& Bukowski, W. (2000). Is gender identity disorder in children a mental disorder? Sex Roles, 43, 753-785. doi:10.1023/A:1011004431889.

Belgrave, F., Reed, M., Plybon, L., Butler, D., Allison, K., \& Davis, T. (2004, August). An evaluation of sisters of Nia: A cultural program for African American girls. Journal of Black Psychology, 30, 329343. doi: $10.1177 / 0095798404266063$. 
Bergström, K., Jonsson, L., \& Shanahan, H. (2010). Children as co-researchers voicing their preferences in foods and eating: Methodological reflections. International Journal of Consumer Studies, 34, 183-189. doi:10.1111/j.1470-6431.2009.00843.x.

Billig, M. (1991). Ideology and opinions: Studies in rhetorical psychology. Thousand Oaks, CA: Sage Publications.

Bornmann, L., \& Daniel, H. (2008). What do citation counts measure? A review of studies on citing behavior, Journal of Documentation, 1, 45-80.

Bradshaw, G.A. (2009). Elephants on the edge: What animals teach us about humanity. New Haven, CT: Yale University Press.

Brown, P.L. (2006, December 2). Supporting boys or girls when the line isn't clear. The New York Times. Retrieved from http://www.nytimes.com/2006/12/02/us/02child.html

Browne, K. (2004). Genderism and the bathroom problem: (Re)materialising sexed sites, (re)creating sexed bodies. Gender Place and Culture, 11(3), 331-346.

Bryant, K. (2006). Making gender identity disorder of childhood: Historical lessons for contemporary debates. Sexuality Research \& Social Policy: A Journal of the NSRC, 3, 23-39. doi:10.1525/srsp.2006.3.3.23.

Bryant, K. (2008). In defense of gay children? 'Progay' homophobia and the production of homonormativity. Sexualities, 11(4), 455-475. doi:10.1177/1363460708091744.

Buhrke, R.A., Ben-Ezra, L.A., Hurley, M.E., \& Ruprecht, L.J. (1992). Content analysis and methodological critique of articles concerning lesbian and gay male issues in counseling journals. Journal of Counseling Psychology, 39(1), 91-99. doi:10.1037/0022-0167.39.1.91.

Buijs, C. (1996, April 16). A new perspective on an old topic. Posted on soc.support. transgendered news group. Retrieved from http//groups.google.com/group/soc.support. transgendered $/ \mathrm{msg} / 184850 \mathrm{df} 15 \mathrm{e} 48963$ ?hl=en $\&$ pli=1

Bulilan, C.M.R. (2008, December 10). Japanese youngsters'fashion: A transgender language. Retrieved from http://api.ning.com/files/ cQeIFs4ou9PtFSnltu4Vca QAOWb7EQrkk* YseaMZ w4N7EOfbKjZvZjgmcWPuxO * GAe* VvsHuDrLqNK0Xjr5EnMNhtAf3ZvcV /Experiencing CulturalHeritageAndIndigenousTourisminBanaue.pdf

Burke, P. (1996). Gender shock: Exploding the myths of male and female. New York, NY: Anchor Books/Doubleday.

Burman, E., Gowrisunkur, J., \& Sangha, K. (1998). Conceptualising cultural and gendered identities in psychological therapies. European Journal of Psychotherapy \& Counselling, 1, 231-255.

Conroy, H., \& Harcourt, D. (2009). Informed agreement to participate: Beginning the part- nership with children in research. Early Child Development and Care, 179, 157-165. doi:10.1080/03004430802666973.

Crasnow, S. (2008). Feminist philosophy of science: 'standpoint' and knowledge. Science \& Education, 17, 1089-1110. doi: 10.1007/s11191-006-9069-z.

Danziger, K. (1990). Constructing the subject: Historical origins of psychological research. New York, NY: Cambridge University Press.

Davies, S.G. (2007). Challenging gender norms: Five genders among the Bugis in Indonesia (Case Studies in Cultural Anthropology. Belmont, CA: Wadsworth.

de Beauvoir, S. (1949/1974). The second sex. New York, NY: Random House.

Defosse, D.L. (1994, May 26). Transgender research. Posted on alt.transgendered newsgroup. Retrieved from http //groups.google.com/group/alt.transgendered/browse_thread/thread/69c04e35666a9a1b/69ebd e0bf2af8dc6?lnk =st\&q= cisgendered+dana+defosse \&rnum $=1 \&$ hl $=$ en $\&$ done $=/$ group $/$ alt.transge ndered/browse_thread/thread/69c04e35666a9a1b/69ebde0bf2af8dc6\%3Flnk\%3Dst\%26q\%3Dcisgen dered\%2Bdana\%2Bdefosse\%26rnum\%3D1\%26hl\%3Den

de Solla Price, D.J., \& Beaver, D. (1966). Collaboration In an invisible college. American Psychologist, 21(11), 1011-1018. doi:10.1037/h0024051.

Diekman, A.B., Eagly, A.H., \& Johnston, A.M. (2010). Social structure. In J.F. Dovidio, M. Hewstone, P. Glick, \& V.M. Esses (Eds.), The Sage handbook of prejudice, stereotyping, and discrimination (pp. 209-224). New York: Sage.

Dimensions Clinic (2007). Hormone info. Retrieved from http:/www.dimensionsclinic.org/transgroup.html

Drummond, K., Bradley, S., Peterson-Badali, M., \& Zucker, K. (2008). A follow-up study of girls with gender identity disorder. Developmental Psychology, 44, 34-45. doi:10.1037/00121649.44.1.34.

DuBois, W.E.B. (1903/2005). The souls of Black folk (C.B. Johnson, Ed.). New York, NY: Simon \& Schuster. 
Edwards, L., \& Pedrotti, J. (2008). A content and methodological review of articles concerning multiracial issues in six major counseling journals. Journal of Counseling Psychology, 55, 411-418. doi:10.1037/0022-0167.55.3.411.

Eichler, M. (1991). Nonsexist research methods: A practical guide. London: Routledge.

Fairchild, H. (1991). Scientific racism: The cloak of objectivity. Journal of Social Issues, 47, 101-115.

Fernando, S. (1988). Race and culture in psychiatry. New York, NY: Croom Helm.

Fernando, S. (2009). Inequalities and the politics of 'race' in mental health. In S. Fernando \& F. Keating (Eds.), Mental health in a multi-ethnic society: A multidisciplinary handbook (2nd ed., pp. 42-57), New York, NY: Routledge/Taylor \& Francis Group.

Foley, J.A., \& Della Sala, S. (2010). The impact of self-citation. Cortex: A Journal Devoted to the Study of the Nervous System and Behavior, 46(6), 802-810. doi:10.1016/j.cortex.2010.01.004.

Freud, S. (1960). The ego and the id. (J. Riviere, Trans.). New York, NY: W. W. Norton. (Original work published 1923).

Gannon, L., Luchetta, T., Rhodes, K., Pardie, L., \& Segrist, D. (1992). Sex bias in psychological research: Progress or complacency? American Psychologist, 47, 389-396. doi:10.1037/0003066X.47.3.389.

Gay \& Lesbian Alliance Against Defamation (GLAAD). (2010). GLAAD Media reference guide: AP, The New York Times, \& Washington Post style. Retrieved from http://www.glaad. org/Page.aspx?pid=380

Giordano, S. (2008). Lives in a chiaroscuro. Should we suspend the puberty of children with gender identity disorder? Journal of Medical Ethics, 34, 580-584.

Graham, S. (2004). It's like one of those puzzles: Conceptualising gender among Bugis. Journal of Gender Studies, 13, 107-116. doi:10.1080/0958923042000217800.

Green, R., \& Money, J. (1960). Incongruous gender role: Nongenital manifestations in prepubertal boys. Journal of Nervous and Mental Disease, 131, 160-168.

Green, R., \& Money, J. (1961). Effeminacy in prepubertal boys. Summary of eleven cases and recommendations for case management. Pediatrics, 27, 286-291.

Green, R., \& Money, J. (1962). Binocular rivalry of gender-significant pictures in a stereoscope. Journal of Psychiatric Research, 2(1), 153-161. doi:10.1016/0022-3956(62)90005-5.

Hampson, J.L., Hampson, J.G., \& Money, J. (1955). The syndrome of gonadal agenesis (ovarian agenesis) and male chromosomal pattern in girls and women: Psychologic studies. Johns Hopkins Hospital Bulletin, 97, 207-226.

Haslam, N., \& Levy, S. (2006). Essentialist beliefs about homosexuality: Structure and implications for prejudice. Personality and Social Psychology Bulletin, 32, 471-485. doi:10.1177/0146167205276516.

Head, J. (2008). Thai school offers transsexual toilet. BBC News. Retrieved from http://news.bbc.co.uk/1/hi/world/asia-pacific/7529227.stm

Hegarty, P. (2007). From genius inverts to gendered intelligence: Lewis Terman and the power of the norm. History of Psychology, 10(2), 132-155. doi:10.1037/1093-4510.10.2.132.

Hegarty, P. (2009). Toward an LGBT-informed paradigm for children who break gender norms: Comment on Drummond et al. (2008) and Rieger et al. (2008). Developmental Psychology, 45, 895900. doi:10.1037/a0016163.

Herek, G., Kimmel, D., Amaro, H., \& Melton, G. (1991). Avoiding heterosexist bias in psychological research. American Psychologist, 46, 957-963. doi:10.1037/0003-066X.46.9.957.

Herek, G.M. (1990). The context of anti-gay violence: Notes on cultural and psychological heterosexism. Journal of Interpersonal Violence, 5, 316-333.

Herek, G.M. (2000). The psychology of sexual prejudice. Current Directions in Psychological Science, 9, 19-22.

Hill, D., Menvielle, E., Sica, K., \& Johnson, A. (2010). An affirmative intervention for families with gender variant children: Parental ratings of child mental health and gender. Journal of Sex \& Marital Therapy, 36, 6-23. doi:10.1080/00926230903375560.

Hill, D., Rozanski, C., Carfagnini, J., \& Willoughby, B. (2005). Gender identity disorders in child- hood and adolescence: A critical inquiry. Journal of Psychology \& Human Sexuality, 17, 7-33. doi:10.1300/J056v17n03_02.

Hill, D., \& Willoughby, B. (2005). The development and validation of the Genderism and Transphobia Scale. Sex Roles, 53, 531-544. doi:10.1007/s11199-005-7140-x.

Honingmann, J.J. (1964). The Kaska Indians: An ethnographic reconstruction. New Haven, CT: Yale University Press. 
Hyde, J. (1984). Children's understanding of sexist language. Developmental Psychology, 20, 697-706. doi:10.1037/0012-1649.20.4.697.

Imada, T., \& Schiavo, R. (2005). The use of ethnic minority populations in published psychological research, 1990-1999. Journal of Psychology: Interdisciplinary and Applied, 139(5), 389-400. doi:10.3200/JRLP.139.5.389-400.

International Conference on Transgender Law and Employment Policy (ICTLEP). (1993). Health Law Standards of Care for transsexualism. Second International Conference on Transgender Law and Employment Policy. Retrieved from http://www.altsex.org/transgender/healthlaw.html

Jiménez-Domínguez, B. (2009). Ignacio Martín-Baró's social psychology of liberation: Situated knowledge and critical commitment against objectivism. In M. Montero \& C.C. Sonn (Eds.), Psychology of liberation: Theory and applications (pp. 37-50). New York, NY: Springer Science \& Business Media.

Keller, J. (2005). In genes we trust: The biological component of psychological essentialism and its relationship to mechanisms of motivated social cognition. Journal of Personality and Social Psychology, 88, 686-702. doi:10.1037/0022-3514.88.4.686.

Kennedy, N. (2008, February 20). Growing up in chiaroscuro. The Guardian. Retrieved from http://www.guardian.co.uk/commentisfree/2008/feb/20/growingupinchiaroscuro

Kielburger, C., \& Kielburger, M. (2009, November 20). Marking UNCRC anniversary by honoring commitment to children [Web log message]. Retrieved from http://www.huffingtonpost.com/ craigand-marc-kielburger/marking-uncrc-anniversary_b_365697.html; http://www.huffington post.com/

Kitzinger, C. (1987). The social construction of lesbianism. Thousand Oaks, CA: Sage.

Klein, G. (2009). Group-work practice with transgender and gender variant youth. In G.P. Mallon (Ed.), Social work practice with transgender and gender variant youth (2nd ed., pp. 115-121). New York: Routledge/Taylor \& Francis Group.

Koyama, E. (2006). Whose feminism is it anyway? The unspoken racism of the trans inclusion debate. In S. Stryker \& S. Whittle (Eds.), The transgender studies reader (pp. 698-705). New York, NY: Routledge.

Lalonde, R.N., Doan, L., \& Patterson, L.A. (2000). Political correctness beliefs, threatened identities, and social attitudes. Group Processes \& Intergroup Relations, 3(3), 317-336. doi:10.1177/1368430200033006.

Langer, S., \& Martin, J. (2004). How dresses can make you mentally ill: Examining gen- der identity disorder in children. Child \& Adolescent Social Work Journal, 21, 5-23. doi:10.1023/B:CASW.0000012346.80025.f7.

Laqueur, T.W. (1990). Making sex: Body and gender from the Greeks to Freud. Boston, MA: Harvard University Press.

Lelchuk, I. (2006). When is it ok for boys to be girls, and girls to be boys? San Francisco Chronicle. Retrieved from http://www.sfgate.com/cgibin/article.cgi?file=/c/a/2006/08/27/MNGL2KQ8H41.DTL

Lev, A., Alie, L., Ansara, Y., Deutsch, M., Dickey, L., Ehrbar, R., et al. (2010). 'Statement on Gender Incongruence in Children in the DSM-5,'Professionals Concerned With Gender Diagnoses in the DSM.

Lillian, D. (2007). A thorn by any other name: Sexist discourse as hate speech. Discourse \& Society, 18 , 719-740. doi:10.1177/0957926507082193.

Majority World. (n.d.). About us. Retrieved from http://www.majorityworld.org/about_us.html

Marcu, A., \& Chryssochoou, X. (2005). Exclusion of ethnic groups from the realm of human- ity: Prejudice against the Gypsies in Britain and in Romania. Psicología Política, 30, 3041-3056.

Marech, R. (2004, November 26). Transgender youth gaining acceptance/more schools are honouring students' gender identity. San Francisco Chronicle. Retrieved from http://www.sfgate.com /cgi-bin/article.cgi?f=/c/a/2004/11/26/BAG60A1QLB1.DTL\%0D\%0D

Marksamer, J. (2008, March). And by the way, do you know he thinks he's a girl? The failures of law, policy, and legal representation for transgender youth in juvenile delinquency courts. Sexuality Research \& Social Policy: A Journal of the NSRC, 5, 72-92.

Martin-Baró, I. (1985). La desideologización como aporte de la psicología social al desarrollo de la democracia en Latinoamérica. Boletin de la AVEPSO, 8, 3-9.

Martin, C. (1990). Attitudes and expectations about children with nontraditional and traditional gender roles. Sex Roles, 22, 151-165. doi:10.1007/BF00288188. 
Martin, C., \& Parker, S. (1995). Folk theories about sex and race differences. Personality and Social Psychology Bulletin, 21, 45-57. doi:10.1177/0146167295211006.

Martyna, W. (1980). Beyond the 'he/man' approach: The case for nonsexist language. Signs, 5, 482-493. doi:10.1086/493733.

Matzner, A. (2001). The complexities of 'acceptance': Thai student attitudes towards Kathoey. Crossroads: An Interdisciplinary Journal of Southeast Asian Studies, 15(2), 71-93.

Messing, A., Schoenberg, R., \& Stephens, R. (1983). Confronting homophobia in health care set- tings: Guidelines for social work practice. Journal of Social Work \& Human Sexuality, 2, 65-74.

Miller, D., Taylor, B., \& Buck, M. (1991). Gender gaps: Who needs to be explained? Journal of Personality and Social Psychology, 61, 5-12. doi:10.1037/0022-3514.61.1.5.

Mitsuhashi, J., \& Hasegawa, K. (2006). The transgender world in contemporary Japan: The male to female cross-dressers' community in Shinjuku. Inter-Asia Cultural Studies, 7, 202-227. doi:10.1080/14649370600673847.

Mizock, L., \& Lewis, T. (2008). Trauma in transgender populations: Risk, resilience, and clinical care. Journal of Emotional Abuse, 8, 335-354. doi:10.1080/10926790802262523.

Money, J., Hampson, J.G., \& Hampson, J.L. (1955a). An examination of some basic sexual concepts: The evidence of human hermaphroditism. Johns Hopkins Hospital Bulletin, 97301-97319.

Money, J., Hampson, J.G., \& Hampson, J.L. (1955b). Hermaphroditism: Recommendations concerning assignment of sex, change of sex, and psychologic management. Johns Hopkins Hospital Bulletin, 97, 284-300.

Morin, S. (1977). Heterosexual bias in psychological research on lesbianism and male homosexuality. American Psychologist, 32, 629-637. doi:10.1037/0003-066X.32.8.629.

Muñoz, V. (2008, February 29). Toward a decolonizing transgender psychology (for trans people of color). Retrieved from http://aurora.wells.edu/\%E2\%88\%BCvim/Munoz_Decolonial_TransPsy.pdf.

Möller, B., Schreier, H., Li, A., \& Romer, G. (2009). Gender identity disorder in children and adolescents. Current Problems in Pediatric and Adolescent Health Care, 39, 117-143. doi:10.1055/s-0029-1224554.

Nagoshi, J., Adams, K., Terrell, H., Hill, E., Brzuzy, S., \& Nagoshi, C. (2008). Gender differences in correlates of homophobia and transphobia. Sex Roles, 59, 521-531. doi:10.1007/s11199-008-9458-7.

Namaste, V.K. (2000). Invisible lives: The erasure of transsexual and transgendered people. Chicago, IL: The University of Chicago Press.

Newcomb, M. (1996). Adolescence: Pathologizing a normal process. The Counseling Psychologist, 24, 482-490. doi: $10.1177 / 0011000096243008$

NYU Silver School of Social Work. (n.d.) What is the difference between Social Work and Psychology? I am a psychology major and I want a career in counseling. Is Social Work right for me? FAQs, New York University. Retrieved from http://www.nyu.edu/socialwork/faqs/

O'Connor, S.J. (2010). Citations, impact factors and shady publication practices: How should the lasting clinical and social value of research really be measured? European Journal of Cancer Care, 19(2), 141-143. doi:10.1111/j.1365-2354.2010.01178.x.

Parlee, M. (1996). Situated knowledges of personal embodiment: Transgender activists' and psychological theorists' perspectives on 'sex' and 'gender.'. Theory \& Psychology, 6, 625-645. doi:10.1177/0959354396064005.

Peterson, S.B., \& Kroner, T. (1992). Gender biases in textbooks for introductory psychology and human development. Psychology of Women Quarterly, 16(1), 17-36. doi:10.1111/j.14716402.1992.tb00237.x.

Prentice, D., \& Miller, D. (2007). Psychological essentialism of human categories, Current Directions in Psychological Science, 16, 202-206. doi:10.1111/j.1467-8721.2007.00504.x.

Purdie-Vaughns, V., \& Eibach, R. (2008). Intersectional invisibility: The distinctive advan- tages and disadvantages of multiple subordinate-group identities, Sex Roles, 59, 377-391. doi:10.1007/s11199008-9424-4.

Quiñones-Vidal, E., López-García, J.J., Peñarañda-Ortega, M., \& Tortosa-Gil, F. (2004). The nature of social and personality psychology as reflected in JPSP, 1965-2000. Journal of Personality and Social Psychology, 86, 435-452. doi:10.1037/0022-3514.86.3.435.

Raj, R. (2007). Transactivism as therapy: A client self-empowerment model linking personal and social agency. Journal of Gay \& Lesbian Psychotherapy, 11(3-4), 77-98. doi:10.1300/J236v11n03_05. 
Raj, R. (2008). Transforming couples and families: A trans-formative therapeutic model for work- ing with the loved-ones of gender-divergent youth and trans-identified adults. Journal of GLBT Family Studies, 4, 133-163.

Rekers, G., \& Yates, C. (1976). Sex-typed play in feminoid boys versus normal boys and girls. Journal of Abnormal Child Psychology, 4(1), 1-8.

Rekers, G.A., \& Lovaas, O. (1974). Behavioral treatment of deviant sex-role behaviors in a male child. Journal of Applied Behavior Analysis, 7(2), 173-190. doi:10.1901/jaba.1974.7-173.

Rekers, G.A., Rosen, A.C., Lovaas, O., \& Bentler, P.M. (1978). Sex-role stereotypy and profes- sional intervention for childhood gender disturbance. Professional Psychology, 9(1), 127-136. doi:10.1037/0735-7028.9.1.127.

Rekers, G.A., \& Varni, J.W. (1977). Self-monitoring and self-reinforcement processes in a pretranssexual boy. Behaviour Research and Therapy, 15(2), 177-180. doi:10.1016/00057967(77)90102-4.

Roen, K. (2011). The discursive and clinical production of trans youth: Gender variant youth who seek puberty suppression. Psychology \& Sexuality, 2(1), 58-68.

Rosenberg, M. (2002). Children with gender identity issues and their parents in individual and group treatment. Journal of the American Academy of Child \& Adolescent Psychiatry, 41, 619-621. doi:10.1097/00004583-200205000-00020.

Roughgarden, J. (2004). Evolution's rainbow: Diversity, gender, and sexuality in nature and people. Berkeley, CA: University of California Press.

Sandor, D. (2007). Re Alex: Hormonal Treatment for Gender Identity Dysphoria [2004] FamCA 297 (13 April 2004). Retrieved from http://www.austlii.edu.au/au/cases/cth/ family_ct/2004/297.html

Schechter, N.L. (1989). The undertreatment of pain in children: An overview. Pediatric Clinics of North America, 36, 781-94.

Schweimler, D. (2007). Argentine boy sex change approved. Retrieved from http://news.bbc.co.uk/1/hi/world/americas/7013579.stm

Serano, J. (2007). Whipping girl: A transsexual woman on sexism and the scapegoating of femininity. Berkeley, CA: Seal Press.

Sherif, C. (1998). Bias in psychology. Feminism \& Psychology, 8, 58-75. doi:10.1177/0959353598081005.

Simoni, J.M. (1996). Confronting heterosexism in the teaching of psychology. Teaching of Psychology, 23, 220-226.

Singh, D. (2001). Myself Mona Ahmed. Zurich/New York, NY: Scalo Verlag.

Spanier, B.B. (1995). Im/partial science: Gender ideology in molecular biology. Bloomington and Indianapolis, IN: Indiana University Press.

Spiegel, A. (2008). Two families grapple with sons' gender preferences. National Public Radio. Retrieved from http://www.npr.org/templates/story/story.php?storyId=90247842

Stanley, L., \& Wise, S. (1983). Breaking out: Feminist consciousness and feminist research. London: Routledge and Kegan Paul.

Sugano, E., Nemoto, T., \& Operario, D. (2006). The impact of exposure to transphobia on HIV risk behavior in a sample of transgendered women of color in San Francisco. AIDS and Behavior, 10, 217-224. doi:10.1007/s10461-005-9040-z.

Tee, N., \& Hegarty, P. (2006). Predicting opposition to the civil rights of trans persons in the United Kingdom. Journal of Community \& Applied Social Psychology, 16, 70-80.

Tucker, J., \& Jürgen Keil, H. (2002). Can cultural beliefs cause a gender identity disorder? Journal of Psychology \& Human Sexuality, 13, 21-30. doi:10.1300/J056v13n02_02.

United Nations Convention on the Rights of the Child (1989). UN General Assembly. New York, NY: UNICEF.

Vanderburgh, R. (2009). Appropriate therapeutic care for families with pre-pubescent transgender/gender-dissonant children. Child \& Adolescent Social Work Journal, 26, 135-154. doi:10.1007/s10560-008-0158-5.

Vasey, P., \& Bartlett, N. (2007). What can the Samoan 'fa'afafine' teach us about the western concept of gender identity disorder in childhood? Perspectives in Biology and Medicine, 50, 481-490.

Voss, J., \& Gannon, L. (1978). Sexism in the theory and practice of clinical psychology. Professional Psychology, 9, 623-632. doi:10.1037/0735-7028.9.4.623.

Walco, G.A., Cassidy, R.C., \& Schechter, N.L. (1994). Pain, hurt, and harm: The ethical issue of pediatric pain control. New England Journal of Medicine, 331, 541-544. 
Warner, M. (Ed.). (1993). Fear of a queer planet: Queer politics and social theory. Minneapolis, MN: University of Minnesota Press.

Weinberg, G. (1973). Society and the healthy homosexual. New York, NY: Anchor Books.

Weisman, S.J., Bernstein, B., \& Schechter, N.L. (1998). Consequences of inadequate analgesia during painful procedures in children. Archives of Pediatrics and Adolescent Medicine, 152,

147-149.

Williams, M., \& Eberhardt, J. (2008). Biological conceptions of race and the motivation to cross racial boundaries. Journal of Personality and Social Psychology, 94, 1033-1047. doi:10.1037/00223514.94.6.1033.

Williams, W.L. (1992). The spirit and the flesh: Sexual diversity in American Indian culture. Boston, MA: Beacon Press.

Wilson, I., Griffin, C., \& Wren, B. (2002). The validity of the diagnosis of gender identity disorder (child and adolescent criteria). Clinical Child Psychology and Psychiatry, 7, 335-351. doi:10.1177/1359104502007003032.

Winter, S. (2006). Thai transgenders in focus: Their beliefs about attitudes towards and origins of transgender. International Journal of Transgenderism, 9(2), 47-62. doi:10.1300/J485v09n02_06.

Winter, S., Webster, B., \& Cheung, P. (2008). Measuring Hong Kong undergraduate students' attitudes towards transpeople. Sex Roles, 59, 670-683.

Winters, K. (2008). Gender madness in American psychiatry: Essays from the struggle for dignity, text revision. Dillon, CO: GID Reform Advocates.

Zucker, K., \& Cantor, J. (2005). The impact factor: 'Goin' up'. Archives of Sexual Behavior, 34, 7-9. doi:10.1007/s10508-005-0997-5.

Zucker, K.J., \& Bradley, S.J. (1995). Gender identity disorder and psychosexual problems in children and adolescents. New York, NY: Guilford Press.

Zucker, K.J., Bradley, S.J., Owen-Anderson, A., Kibblewhite, S.J., \& Cantor, J.M. (2008). Is gender identity disorder in adolescents coming out of the closet? Journal of Sex \& Marital Therapy, 34, 287-290.

Zucker, K.J., Drummond, K.D., Bradley, S.J., \& Peterson-Badali, M. (2009). Troubled meditations on psychosexual differentiation: Reply to Hegarty (2009). Developmental Psychology, 45(4), 904-908. doi:10.1037/a0016125.

\section{Appendix}

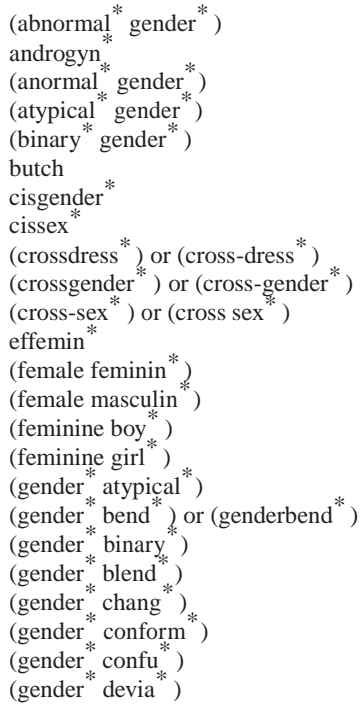




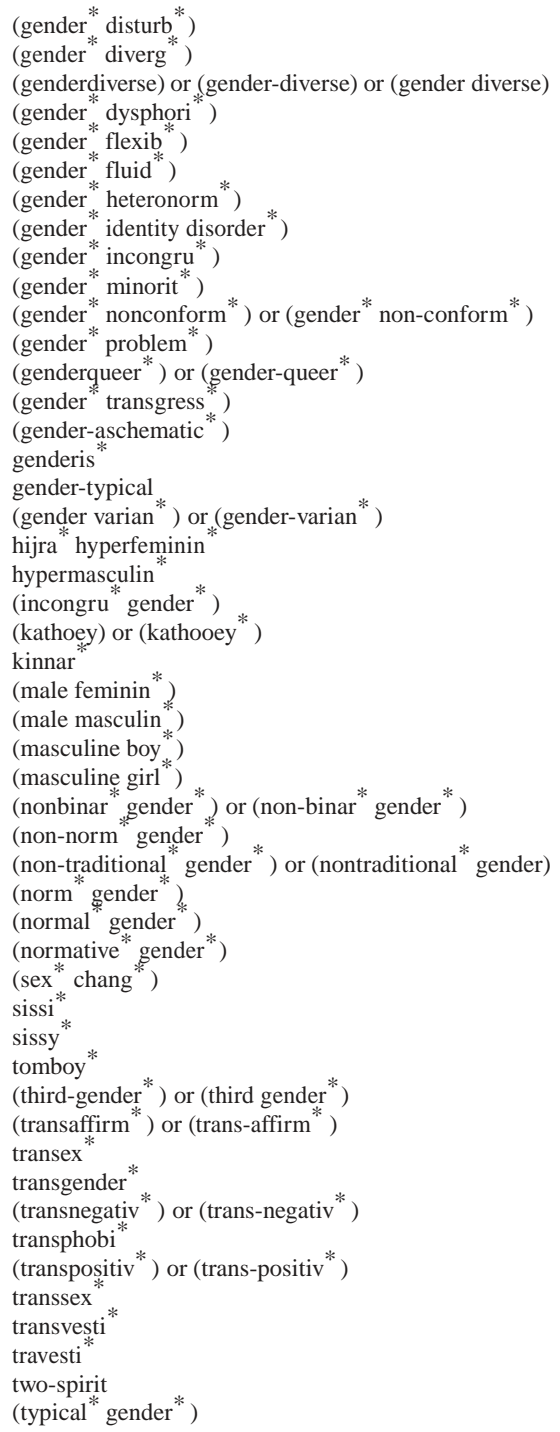

